be published to Regiments and Companies if possible in the hearing of every soldier and translated to our comrades of different languages. A prompt response to a call for duty and a readiness to move with celerity, and a brave exhibition of endurance will command the admiration of our comrade of other fields and receive the cordial commendation of the Commanding General.

By order of Brig Genl Curtis

N. P. Chipman

Maj \& A A A Genl

\title{
LOOKING TO IOWA'S CENTENNIAL
}

With Iowa's statehood centennial only three years away-it will fall in 1946-it isn't too early for our state to begin preparations for an observance worthy of the event. It doesn't require an optimist to think that the war will be victoriously ended by that time.

In 1939 Iowa did an oustanding job of celebrating its territorial centennial. Public morale was measurably lifted by the observances staged in the various towns and counties of the state. The statehood centennial will be an even more auspicious occasion and this should be reflected in a stepped-up observance.

Senator Stewart of Maynard, Fayette county, has introduced in the legislature a bill authorizing the governor to appoint a permanent nine-member Centennial committee to report to the 1945 assembly. A modest appropriation would be provided the state historical department to defray necessary postage and clerical expenses while the groundwork is being laid.

Having been active in the territorial centennial program and observed at close range the benefits which came to Iowa by reason of it, this newspaper is very hopeful that the Stewart measure will have the ready and enthusiastic approval of the legislature.

Now is the time to work if the observance is to be wellplanned. The next legislature will be too late if we want a complete job done. And surely we do. - Mason City Globe-Gazette, March 25, 1943. 
Copyright of Annals of Iowa is the property of State of Iowa, by \& through the State Historical Society of Iowa and its content may not be copied or emailed to multiple sites or posted to a listserv without the copyright holder's express written permission. However, users may print, download, or email articles for individual use. 